\title{
Carbon financial markets underlying climate risk management, pricing and forecasting: Fundamental analysis
}

\author{
http://doi.org/10.21272/fmir.4(4).31-44.2020
}

Adil El Amri, ORCID: https://orcid.org/0000-0003-1849-8727

Professor, Member of LERSEM Laboratory, National School of Business and Management (ENCG) El Jadida, Coordinator: Professional Bachelor's degree: Management \& Administration of Organizations, F.P.S.B., University of Chouaib Doukkali, El Jadida, Morocco

\section{Rachid Boutti}

Professor, President of the Chair UNESCO Sustainable Development, Founder of LaRGe Laboratory, Director of the CREMA Indexed International Journal and Expert at the CNRS, ENCG, UIZ, Agadir, Morocco

\section{Salah Oulfarsi}

Professor, Member of LERSEM Laboratory, National School of Business and Management (ENCG) El Jadida, University of Chouaib Doukkali, El Jadida, Morocco

\section{Florence Rodhain}

Professor, Director of the MRM-SI Research Team, University Polytechnic School, University of Montpellier, Montpellier, France

\section{Brahim Bouzahir}

Professor, Member of LERSEM Laboratory, National School of Business and Management (ENCG) El Jadida, University of Chouaib Doukkali, El Jadida, Morocco

\begin{abstract}
Climate Change (CC) is a major issue of our century. Controlling the constraints of Greenhouse Gas (GHG) emissions through transformation into opportunities, in an organization to increase industrial production, has become a necessity. The main reason for this adoption was the effectiveness of energy management and responsible linkages that are being developed to determine the issues and opportunities of carbon finance for organizations. Through analysis of the European Union Emissions Trading Scheme (EU ETS) and the Clean Development Mechanism (CDM), this article presents and demonstrates a variety of determinants of $\mathrm{CO} 2$ prices (EUA) to be used in econometric techniques. This paper details the main carbon price drivers related to institutional decisions, energy prices and weather events. Our study focuses on price changes in the EUA, being the most liquid carbon asset. In this regard, we highlighted the daily spot price of the EUA to highlight the daily changes affecting this price, given the high volatility in this Carbon financial market. The treatments of the determinants of $\mathrm{CO} 2$ prices (EUA) can be used to analyze the evolving and expanding Carbon financial markets sphere. It features stylized facts about Carbon financial markets from an economics and management perspective, as well as covering key aspects of pricing strategies (institutional decisions, energy prices and extreme weather events), risk and portfolio management. Aimed at those with fundamental analysis, the $\mathrm{CO} 2$ prices within the framework of the EU ETS depend on several determinants. This paper constitutes an introduction to emission trading and an overview of the regulations governing Carbon financial markets. First, we detail the price changes in the EUA and primary energy prices. Second, we introduce the main characteristics of emissions trading, be it in terms of spatial and temporal limits, Clean Dark Spread, Clean Spark Spread and Switch Price. Third, we provide a descriptive analysis of atmospheric variables, structural variations and the Subprime crisis and their impacts in the price development of EU CO2 allowances.
\end{abstract}

Keywords: Fundamental analysis, European Union Emissions Trading Scheme, Clean Development Mechanism (CDM), Determinants of $\mathrm{CO} 2$ prices (EUA), Climate risk management.

JEL Classification: G30, O16, Q01, Q51, Q54.

This work is licensed under a Creative Commons Attribution 4.0 International License

Cite as: El Amri, A., Boutti, R., Oulfarsi, S., Rodhain, F., Bouzahir, B. (2020). Carbon financial markets underlying climate risk management, pricing and forecasting: Fundamental analysis. Financial Markets, Institutions and Risks, 4(4), 31-44. http://doi.org/10.21272/fmir.4(4).31-44.2020.

(C) The Authors, 2020. This article is published with open access at Sumy State University. 


\section{Introduction}

The field of Sustainable Finance through the lens of Responsible Management seems more occupied by the managers than by the economists. Thus it is that among the many works devoted to this theme, few have studied specifically the performance of the adoption of Sustainable Finance, while the latter are the preferred vehicle of implementation and the deployment of Sustainable Finance (El Amri, Boutti, Rodhain, 2020). The scientific community began to take an interest in Climate Change (CC) in the 1970s. There is now a broad consensus on the responsibility for human-induced greenhouse gas (GHG) emissions in since the end of the pre-industrial era. The international community has since agreed on the need to act quickly to reduce them in order to limit the scale of future climate change. According to the IPCC, global average temperature could rise from $1.1^{\circ} \mathrm{C}$ to $6.4^{\circ} \mathrm{C}$ by the end of the century. Given the disruptions, the consensus of states reached in Copenhagen and Durban aims to limit the increase in the average temperature of the planet to two degrees compared to the pre-industrial levels. To stay under this limit, scientific experts believe that at least half of global greenhouse gas emissions must be halved by 2050 (Bunn and Fezzi, 2007). Global warming is increasingly seen by investors as a long-term risk factor that could have a negative impact on asset valuation (Alberola and Chevallier, 2009). In this context, a set of approaches and methodologies have been defined in recent years to evaluate the contributions of different sources of greenhouse gas (GHG) emissions, to quantify $\mathrm{CO} 2$ emissions and to Progress reports for a Sustainable Development. This transitional path involves a reorientation of part of the amounts invested in the carbon intensive sectors to the low-carbon sectors (Broome, 1992). To respond to the challenges of climate change, a major reorientation of these approaches and methodologies is primordial. These strategies generate a reallocation of $\mathrm{CO} 2$ emissions, enabling industrial companies to first make an objective assessment of their emissions and to shed light on the resulting priorities (given the carbon limits recommended). The EU ETS to better understand the risks associated with Climate Change (CC) and to identify financial development opportunities related to GHG emissions (Alberola, Chevallier, Cheze, 2008), thus presenting existing CO2 pricing practices (EUA) By means of the econometric analysis of the two phases of the EU ETS.

$\mathrm{CO} 2$ prices in the context of the EU ETS depend on several determinants (variables). Following this principle, it can be said that the real objective of the EU ETS to offer incentives to industrial firms to reduce their CO2 emissions, and therefore promote the adoption of low-carbon technologies, develop Efficiency Energy (EE) and Renewable Energies (RE).

We thus specify the panorama of regulations governing carbon finance.

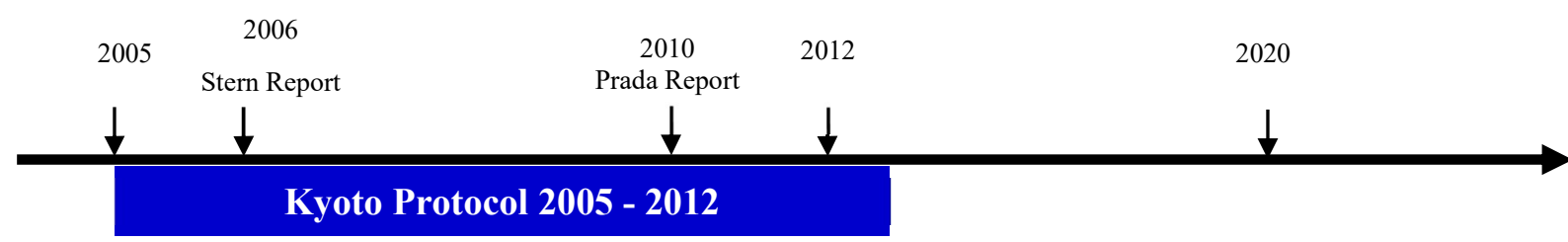

European Union Emissions Trading Scheme (EU ETS)

\begin{tabular}{l|l|l}
$2005-2007$ & $2008-2012$ & $2013-2020$
\end{tabular}

Figure 1. Overview of regulations governing carbon finance

Source: Boutti and al. (2019).

The figure above highlights the three main phases surrounding carbon finance. In 2006 (during phase I), the Stern report ${ }^{1}$ established a price on "the environmental threat of Climate Change". With this in mind, in 2010 (during phase II), the Prada report made twenty-eight (28) technical recommendations for the correct regulation of carbon markets. The establishment of the European permit market pursued nine (9) major phases:

1. March 2002: Commission communication proposing a directive establishing a greenhouse gas (GHG) emission allowance market for the most energy-intensive sectors;

\footnotetext{
${ }^{1}$ Nicholas STERN, former chief economist at the World Bank. The "Stern Report", delivered to Tony Blair in October 2006 highlighted Climate Change in the economic sphere setting a price on the environmental threat.
} 
Financial Markets, Institutions and Risks, Volume 4, Issue 4, 2020 ISSN (online) - 2521-1242 ISSN (print) - 2521-1250

2. October 2003: adoption of Directive 2003/87 / EC of the European Parliament and of the Council establishing a greenhouse gas (GHG) emission allowance trading system in the Community;

3. October 2004: adoption of Directive 2004/101 / EC of the European Parliament and of the Council creating a link between the Community greenhouse gas (GHG) emission allowance trading system and the Kyoto Protocol project mechanisms;

4. January 2005: start-up of the European market for $\mathrm{CO} 2$ emission quotas for the first operating period spread over three years, 2005-2007;

5. June 2005: launch by the Commission of a public consultation on the revision of Directive 203/87;

6. Before June 30, 2006:

$>\quad$ Proposals from the European Commission (EC) for the mid-term review of the functioning of the European market;

Submission by Member States of National Quota Allocation Plans (PNAQ) for the period 2008-

2012.

1. 2008-2012: second period of operation of the European market corresponding to the first period of compliance with Kyoto commitments.

2. 2013-2020: third period of operation of the European market corresponding to a single ceiling for the entire European Union replacing the old system of national ceilings, auctioning and 300 million allowances are allocated to the reserve for New Entrant Reserve (NER 300 program)

3. 2013-2020: fourth period of operation of the European market corresponding to the strengthening of the market stability reserve (mechanism set up by the EU in 2015 to reduce the surplus of emission allowances on the carbon market and improve the resilience of the ETS -EU facing future shocks);

\section{Literature Review}

Following the pioneering work by Christiansen and al. (2005), Chevallier (2012) produced the first literature reviews on the carbon price development in their respective publications. This work was further elaborated by Lebatt and White (2007).

Based on economic analysis (essentially demand and supply fundamentals), Christiansen et al. (2005) have identified the following factors as being the price determinants in the EU ETS: strategy and regulatory issues; market fundamentals, the role of fuel-switching, weather and production levels. Christiansen and al. (2005) and Alberola et al. (2008) were he first analyses to uncover econometrically the relations between energy markets and the $\mathrm{CO} 2$ price.

Based on Phase I spot and futures data, the former group of authors emphasizes that the nature of this relationship between energy and carbon prices varies depending on the period under consideration (Phase I, Phase II or Phase III), and the major influence of institutional events.

In addition, Bunn and Fezzi (2007) have studied the causalities between CO2 and electricity variables (such as Clean Dark and Clean Spark Spreads, and switch price) during the first phases of the EU ETS.

Lebatt and White (2007) underlines a primordial element in functioning of EU ETS, to know the incorporation of two of three mechanisms of suppleness of Kyoto, even in the first stage (2005-2007), before the second stage (2008-2010), particularly, the Negotiable Emissions Permits (PEN) and the Mechanisms of Clean Development (MDP).

Faced with this official report, these last two mechanisms are developed to support firms (or countries) to accomplish their discounts allocated by programs $\mathrm{CO} 2$, even if there is a space of clarity a lot of use of which is made of these mechanisms as percentage of the complete objective of discount of programs.

Finally, it is worth highlighting the work by Boutti, El Amri and Rodhain (2019), whose drivers a structural model of allowance price under the assumption of the performance of the Carbon Finance Strategy for Sustainable Finance is based on the reaction of the fundamentals of quota prices of the European Union Emissions Trading Scheme (EU ETS).

The former of group of authors establishes to show econometrically using multiple regression that changes in the price of carbon (EUA) react to changes in primary energy prices (mainly natural gas) during the Phase I : 
2005-2007 test period. Last but not least, macroeconomic fundamentals of carbon prices respond to the impact of the subprime crisis during the phase II: 2008-2010.

\section{The price of carbon}

Our study focuses on the price variations of the EUA, being the most liquid carbon asset. We have highlighted the daily spot price of the EUA to highlight the daily changes affecting its price, given the high volatility in this market (Bourgeois, 2010). In this regard, we study the spot price of the EUA on the most liquid regulated spot markets. We use daily EUA data, taken from Reuters (Bourgeois, 2010) as follows:

$>$ First, the daily EUA spot price traded on Powernext from July 1, 2005 to December 31, 2007 (Phase I);

$>$ Then the EUA Dec08 traded on ECX from January 1, 2008 to April 25, 2008;

$>$ And finally, the daily EUA spot price traded on BlueNext from April 26, 2008 to April 30, 2010 (Phase II).

Table 1. Characteristics of transactions on the stock exchange spot market BlueNext

\begin{tabular}{|l|c|c|c|}
\hline \multicolumn{1}{|c|}{ Spot Market } & USA & CER & SpreadCER-EUA \\
\hline Contract & BlueNext Spot EUA & BlueNext Spot CER & NC \\
\hline Min volume & 1000 tons & 1000 tons & 1000 tons \\
\hline Register & French & Swiss & $\begin{array}{c}\text { French (EUA) } \\
\text { Switzerland (CER) }\end{array}$ \\
\hline
\end{tabular}

Source: El Amri and al. (2020).

On the spot market, BlueNext offers high transaction speed (15 minutes delay) and organizes payment and delivery: the allocation or credit is transferred from the seller's [carbon] account to the seller's account to the transit account BlueNext and finally to the buyer's [carbon] account. The exchange takes place when the CITL register sends the official notification of the quota transfer. The exchange is carried out on the French register for the USA and Swiss for the RECs. The buyer's cash account is debited to the BlueNext transit account then the seller's cash account.

Table 2. Characteristics of transactions on the Stock Exchange Future market BlueNext

\begin{tabular}{|l|l|l|}
\hline \multicolumn{1}{|c|}{ Futures Market } & \multicolumn{1}{c|}{ USA } & \multicolumn{1}{c|}{ CER } \\
\hline Contract & BlueNext Futures EUA & BlueNext Futures CER \\
\hline Underlying asset & USA 2008-2012 & CERs issued by the CDP steering committee and accepted by BlueNext \\
\hline Min volume & 1000 tons & 1000 tons \\
\hline Register & French & Swiss \\
\hline
\end{tabular}

Source: El Amri and al. (2020).

In these circumstances, transaction costs can be graded according to activity (high or low activity), according to the market (spot or future) and finally according to the type of costs (administrative or transaction). According to Boutti and al. (2019) the BlueNext scholarship proposes decreasing costs (tariffs) presented below according to the volumes of transactions carried out.

In this regard, since the buyers of allowances can turn either to the market or to auctions, the two prices should thus be very close. After dealing with the price of carbon, we will focus on the prices of primary energies: price of oil, price of natural gas and price of coal.

\section{Primary energy prices: oil, natural gas and coal}

The price of primary energy has an effect on the prices of allowances. In this regard, when there is an increase in the price of oil and gas, the use of coal to produce energy is seen on the rise. Following this principle, we can say that $\mathrm{CO} 2$ emissions increase, which leads to an increase in the price of allowances (El Amri, Boutti, Rodhain, 2020). In order to achieve this, we analyze the future prices of primary energies to show the price variations of the EUA (European Union Allowance) according to the needs of industrial firms, when the carbon market is launched. The future markets for these energies are the most liquid. The data was taken from Reuters in Bourgeois (2010).

The brent price (expressed in Euro/BBL) is the brent crude futures Month Ahead price negotiated on ICE (Fig. 2). The brent is a North Sea deposit: its oil is representative of crudes produced in this region. Therefore, it provides the best characteristics to match other energy variables traded in continental Europe, which enter in 
the determination of carbon price.

The natural gas price used (expressed in Euro/Therm) is the futures Month Ahead natural gas price negotiated on Zeebrugge Hub (Fig. 3). It is the best liquid gas trading market in Europe and has a major influence on the price that European consumers pay for this gas. As such, the Zeebrugge price represents the best proxy of the European gas market price determined close to end-users.

The coal price is the Atntwerp/Rotherdam/Amsterdam (ARA) coal futures Month Ahead price (see Fig. 4), which is the major imported coal in northwest Europe. The ARA coal is expressed in Euro/ton.

In this regard, we distinguish, at this level, the three types of futures contracts, commonly used, namely:

1st futures contract: The oil price (expressed in \$ / barrel) used is the daily brent crude futures Month Ahead price traded on the Intercontinental Futures Exchange;
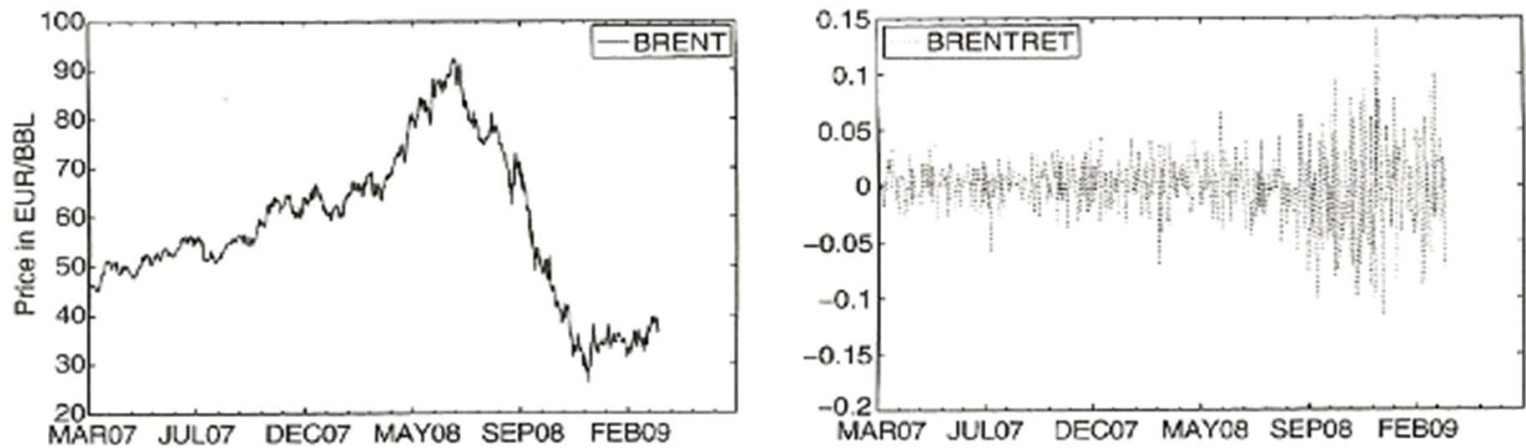

Figure 2. Brent: raw data (left pane) and logreturns (right pane) from March 09, 2007 to March 31, 2009

Source: CHEVALLIER, Julien. Econometric Analysis of Carbon Markets: the European Union Emissions Trading Scheme and the Clean Development Mechanism. p.32.

2nd futures contract: The price of natural gas (expressed in $€ / M W h$ ) used is the daily futures Month Ahead natural gas price negotiated on the Zeebrugge Hub. It is the most liquid gas sold in Europe, and it has a greater influence on the price that European consumers pay for this primary energy (Chevallier, 2012);
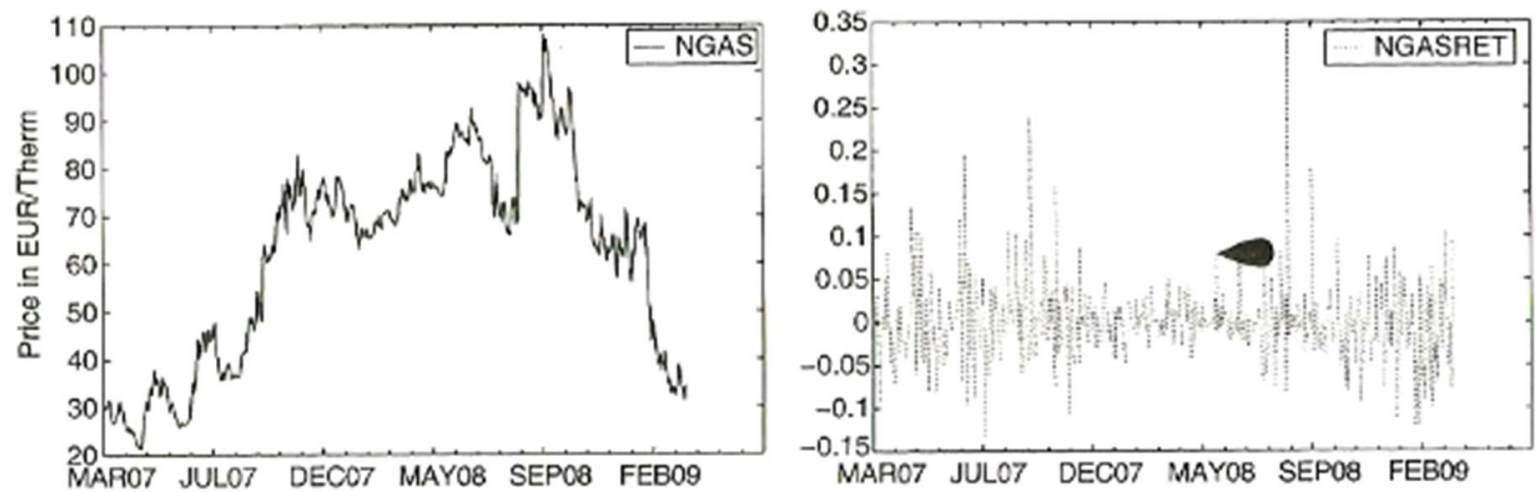

Figure 3. Natural gas: raw data (left pane) and logreturns (right pane) from March 09, 2007 to March 31, 2009

Source: CHEVALLIER, Julien. Econometric Analysis of Carbon Markets: the European Union Emissions Trading Scheme and the Clean Development Mechanism. p.32.

3rd futures contract: The coal price (expressed in $€ /$ Tonne) used is the daily coal futures Month Ahead price CIF ARA (ARA : Antwerp / Rotterdam / Amsterdam, is the best coal imported to North East Europe).

The following figure shows in force the evolution of the price of coal via the raw data (left pane) and logreturns (right pane) from March 09, 2007 to March 31, 2009. 

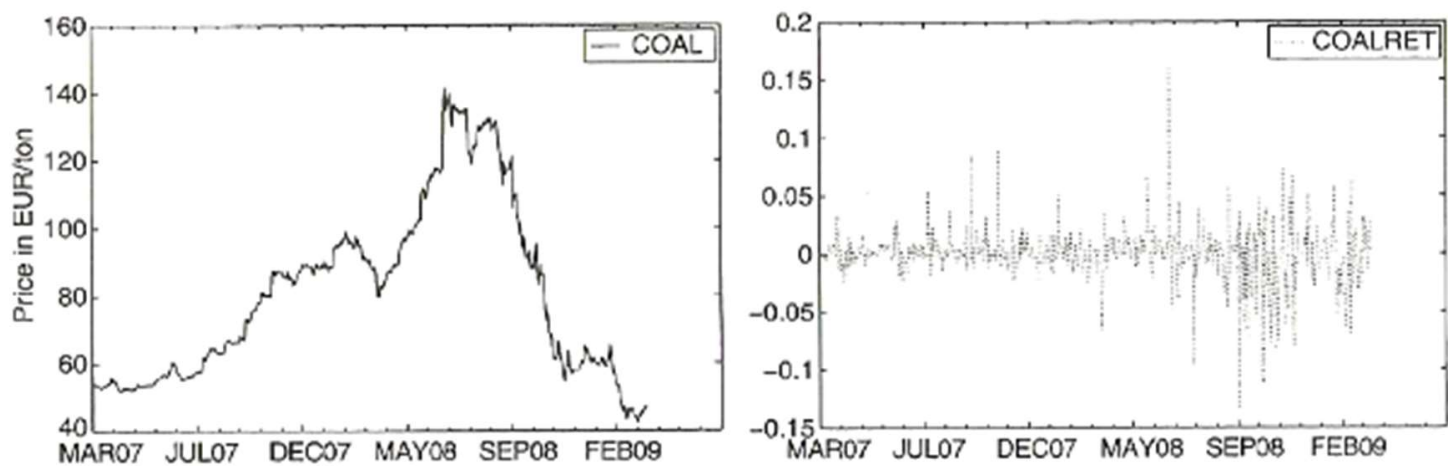

Figure 4. Coal: raw data (left pane) and logreturns (right pane) from March 09, 2007 to March 31, 2009

Source: CHEVALLIER, Julien. Econometric Analysis of Carbon Markets: the European Union Emissions Trading Scheme and the Clean Development Mechanism. p.32.

In accordance with the above, the Responsible Management of these contracts will depend, in one way or another, on the price that the industrial actor is prepared to pay. Boutti et al. (2019) developed problematic questions on the prices of primary energies, in particular gas. After having discussed the prices of primary energies, their contracts and their issues, we will highlight the Clean Dark Spread, the Clean Spark Spread as well as the Switch Price.

\section{The Clean Dark Spread, the Clean Spark Spread and the Switch Price}

Electricity production operators have the possibility of modifying the fuel used for this purpose. In this regard, taking into account a few variables is a sine qua non.

Let us qualify this statement, we detail this idea as follows:

1st variable: The Clean Dark Spread: (expressed in $€$ / MWh) represents the difference between the price of electricity during peak hours (note elec) and the price of coal (noted coal) used to generate and produce electricity, corrected for energy output from coal in the plant and $\mathrm{CO} 2$ costs (noted $p_{t}$ ), as following :

Clean dark $=$ elec $-\left(\right.$ coal $\left.\times \frac{1}{\rho_{\text {coal }}} \times E F_{\text {coal }}\right)$

With $\rho_{\text {coal }}$ is the thermal efficiency of a conventional coal-fired plant, and $E F_{\text {coal }}$ the $\mathrm{CO} 2$ emissions emissions factor of a conventional coal-fired power plant. The Clean Dark Spread is shown in Fig. 5.

The following figure shows the Clean Dark Spread (Price of electricity relative to the price of coal used to produce a unit of electricity) through the raw data (left pane) and logreturns (right section) from March 09, 2007 to March 31, 2009.
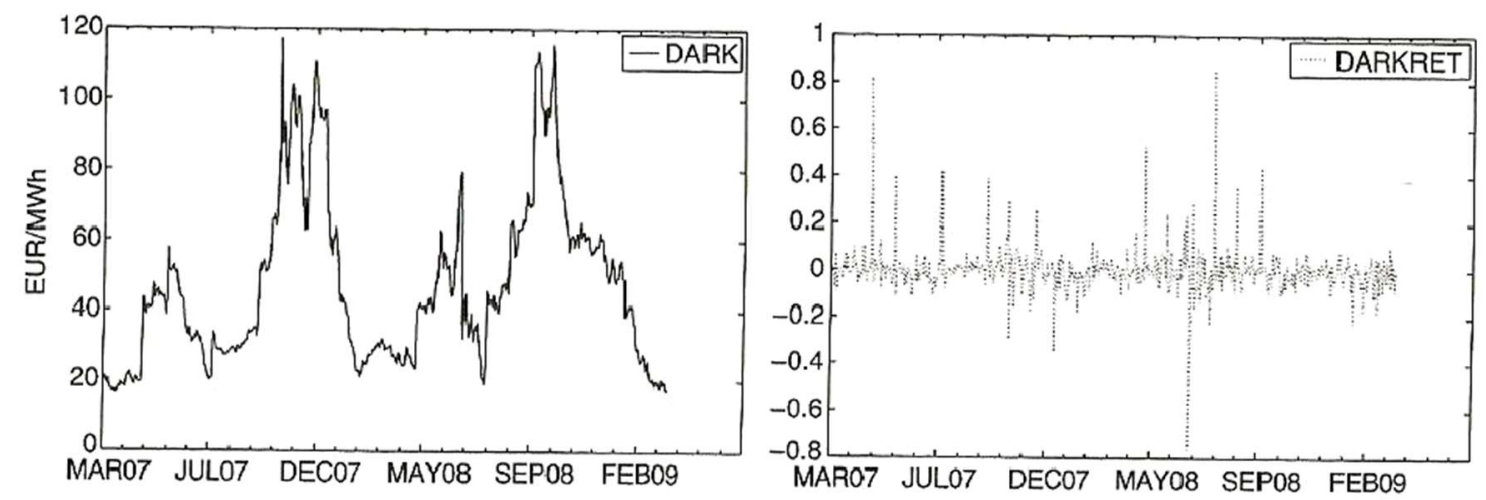

Figure 5. Clean Dark Spread: raw data (left pane) and logreturns (right section) from March 09, 2007 to March 31, 2009

Source: CHEVALLIER, Julien. Econometric Analysis of Carbon Markets: the European Union Emissions Trading Scheme and the Clean Development Mechanism. p.37. 
2nd variable: The Clean Spark Spread: (expressed in $€ / M W h$ ) represents the difference between the price of electricity in peak hours and the price of natural gas (noted ngas) used to generate and produce electricity, corrected for the energy output from fuel gas in the plant and CO2 costs, as follows:

Clean spark $=$ elec $-\left(n g a s \times \frac{1}{\rho_{\text {ngas }}}+p_{t} \times E F_{\text {ngas }}\right)$

With $\rho_{\text {ngas }}$ is the thermal efficiency of the fuel gas in the approved plant, and $E F_{n g a s}$ is the factor of CO2 emissions factor of conventional coal-fired power plant. The Clean Spark Spread is show in Fig. 6.
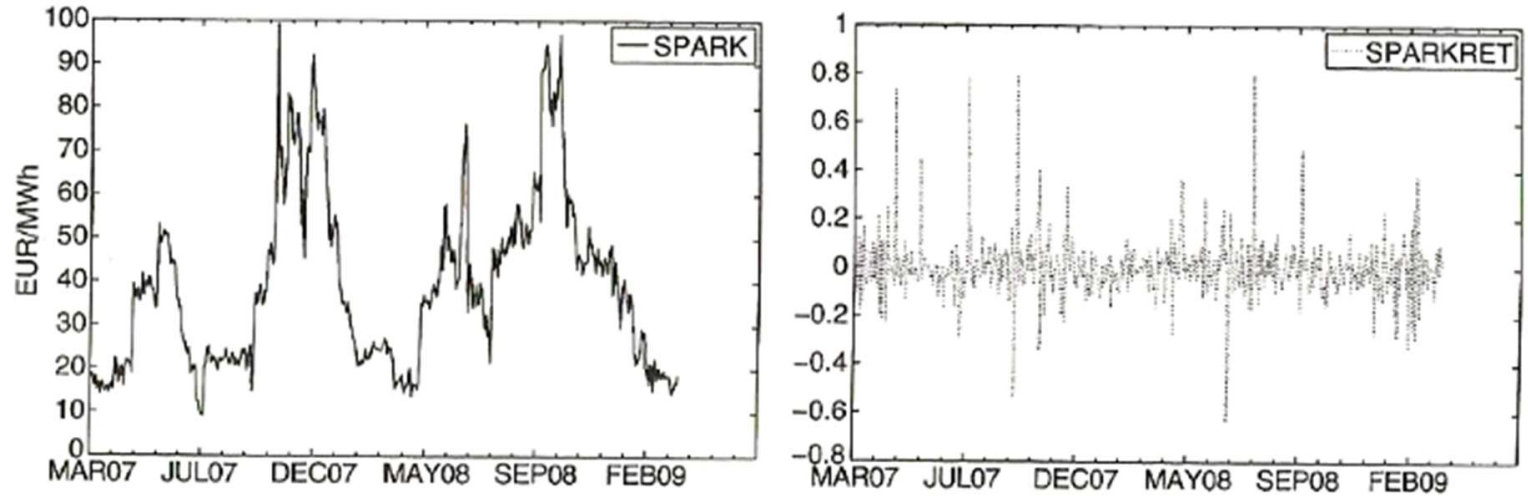

Figure 6. Clean Spark Spread: raw data (left pane) and logreturns (right pane) from March 09, 2007 to March 31, 2009

Source: CHEVALLIER, Julien. Econometric Analysis of Carbon Markets: the European Union Emissions Trading Scheme and the Clean Development Mechanism. p.38.

Clean dark spread and clean spark spread are calculated data. They correspond to the price of electricity (in $€$ $/ \mathrm{MWh}$ ) less the total production cost (respectively coal $+\mathrm{CO} 2$ and gas $+\mathrm{CO} 2$ ) of one unit of electricity (in $€$ / MWh).

3rd variable: The Switch Price: (expressed in $€ / M W h)$ represents the competitive price to equalize the Clean Dark and the Clean Spark, as following:

Switch $=\frac{\text { cost }_{\text {ngas }} / \mathrm{MWh}-\text { cost }_{\text {coal }} / \mathrm{MWh}}{t C O 2_{\text {coal }} / \mathrm{MWh}-t C O 2_{\text {ngas }} / \mathrm{MWh}}$

With cost $_{n g a s}$ is the cost to produce a unit of MWh of electricity based on the net $\mathrm{CO} 2$ emissions of gas (expressed in $€ / \mathrm{MWh}$ ), cost $t_{\text {coal }}$ is the cost to produce a unit of MWh of electricity based on the net $\mathrm{CO} 2$ emissions of coal (expressed in $€ / \mathrm{MWh}$ ), $t C O 2_{\text {coal }}$ is the emission factor (expressed in $t \mathrm{CO} 2 / \mathrm{MWh}$ ) of fuel coal in the approved plant and $t C O 2_{n g a s}$ is the emission factor (expressed in $t \mathrm{CO} 2 / \mathrm{MWh}$ ) of fuel gas in the contracted plant. The figure infra represents the Switch Price.
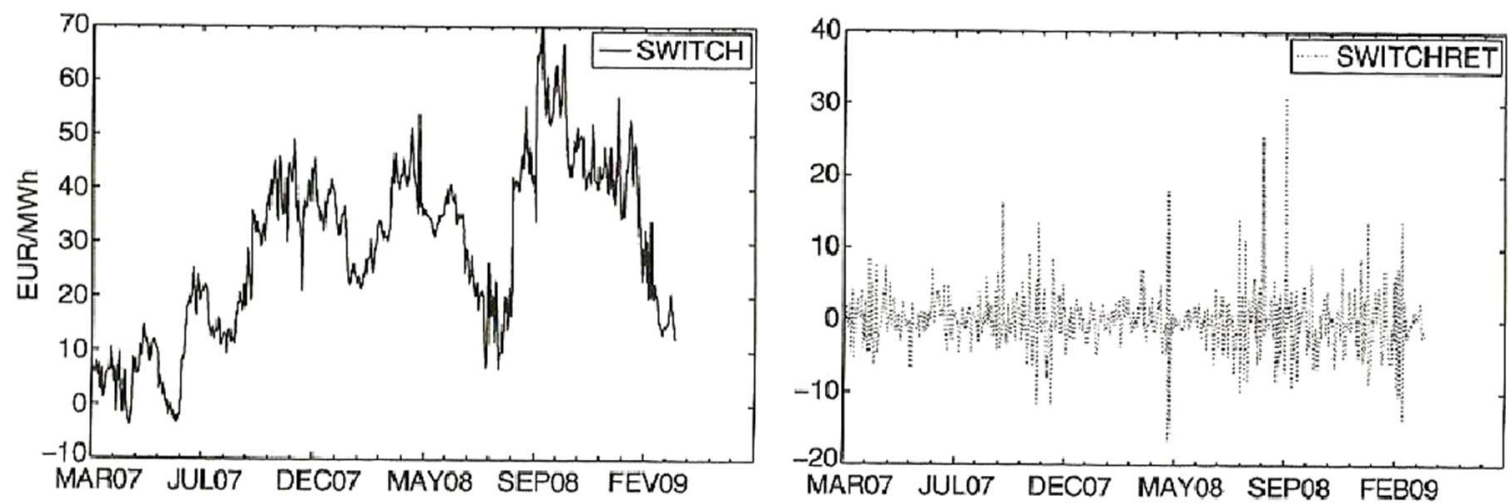

Figure 7. Switch Price: raw data (left pane) and logreturns (right pane) from March 09, 2007 to March 31, 2009

Source: CHEVALLIER, Julien. Econometric Analysis of Carbon Markets: the European Union Emissions Trading Scheme and the 
Clean Development Mechanism. p.38.

According to El Amri, Boutti, Rodhain (2020), the Switch is used to show abatement (or depollution) costs. It is calculated as below:

Switch $=(\mathrm{Rg}-\mathrm{Rc}) /(\mathrm{Ec}-\mathrm{Eg})$

After having tackled the Clean Dark Spread, the Clean Spark Spread as well as the Switch Price, we will develop the weather variables.

\section{Atmospheric variables}

Atmospheric conditions influence the amount of $\mathrm{CO} 2$ emissions. If we are based on this reasoning, we can argue that more energy produced will be concluded by more oil used [in strong connection with $\mathrm{CO} 2$ emissions], and in this end we will need $\mathrm{CO} 2$ allocations (on the carbon market) [in association with a positive effect on $\mathrm{CO} 2$ prices]. Carbon prices (EUA prices) are also related by temperature ${ }^{3}$ of each region using an index called the NBCI "National Business-Climate Index". The latter is defined by an average daily temperature of the region of the country, produced by the population of this region (Chevallier, 2012). This index is expressed in "Celsius Degree $\left(\mathrm{C}^{\circ}\right)^{\prime}$ concerning eighteen (18) countries $^{4}$ as following:

$$
\theta=\frac{\sum_{i=1}^{N} p i \times \theta_{i}}{\sum_{i=1}^{N} p i}
$$

With $\mathrm{N}$ the number of regions in the country under consideration, pi the population of region $\mathrm{i}$, and $\theta_{i}$ the average temperature of region i during the month in question. Moreover, this methodology has been extended by CDC Climat ${ }^{5}$ to take into account the specificities of the carbon market ${ }^{6}$. The European temperature index is equal to the average of the national temperature indices forecast for the eighteen countries, weighted by the weight of each country in the total volume of allowances distributed ${ }^{7}$. We present the formula for this index as

$T=\frac{\sum_{j}^{4} Q_{j} \times \theta_{j}}{\sum_{j=1}^{4} Q_{j}}$

With $\mathrm{T}$ the monthly index, $Q_{j}$ the number of quotas allocated by country $\mathrm{j}$ in its National Quota Allocation Plan (PNAQ), and $\theta_{j}$ the country's national temperature index $\mathrm{j}$.

According to Chevallier (2012), several factors influencing the demand for allowances on the EU ETS carbon market. The most suitable meteorological variables are:

Temperature variations from seasonal norms: a very cold temperature than normal in the winter season enhances energy generation ${ }^{8}$. A warmer temperature in the summer season

\footnotetext{
2with:

$\mathrm{Rg}=$ gas required to produce one unit of electricity with an efficiency of $55 \%$ in $€ / \mathrm{MWh}$;

$\mathrm{Rc}=$ coal necessary to produce a unit with a yield of $40 \%$ in $€ / \mathrm{MWh}$;

$\mathrm{Eg}=\mathrm{CO} 2$ emissions to produce one unit of electricity from gas;

$\mathrm{Ec}=\mathrm{CO} 2$ emissions to produce one unit of electricity from coal.

${ }^{3}$ See Metnext Weather index on the website: http://www.weatherindices.com/index (Page consulted on 02/03/2019).

${ }^{4}$ Austria, Belgium, Germany, Denmark, Spain, Finland, France, United Kingdom, Hungary, Ireland, Italy,

qThe Netherlands, Norway, Poland, Portugal, Sweden, Slovenia and Slovenia.

${ }^{5}$ See website: http://www.cdcclimat.com (Page consulted on 01/23/2019).

${ }^{6}$ CHEVALLIER, Julien. Econometric Analysis of Carbon Markets: the European Union Emissions Trading Scheme and the Clean Development Mechanism. p. 42.

7These data are processed on a weekly basis.

8In particular, the fuel needs for heating matters.
} 
increases energy consumption in relation to air conditioning.

\section{$>$}

Extreme temperature deviations (hot or cold day) from seasonal norms: whatever may be said, an example of the European temperature index is illustrated by the figure below on the left. Said explicit figure Meteorological events: European temperature index and temperatures deviation from the seasonal average in degrees celsius from March 09, 2007 to March 31, 2009.
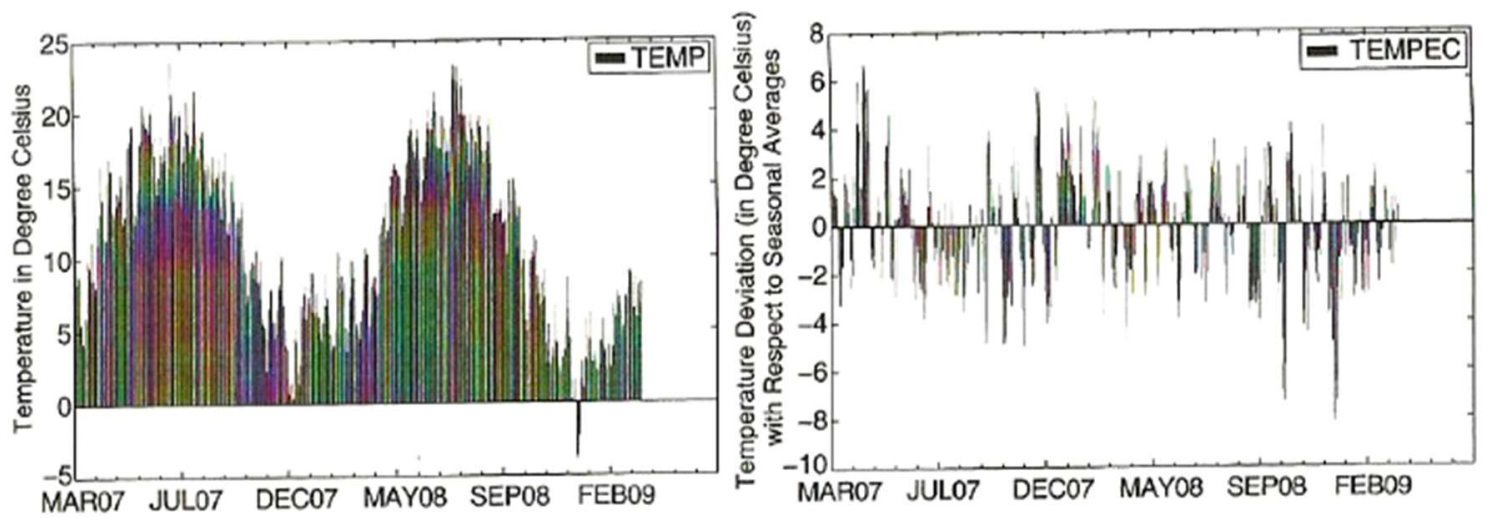

Figure 8. Meteorological events: European temperature index (left side) and the seasonal mean deviation temperatures (right part) in degrees celsius from March 09, 2007 to March 31, 2009

Source: CHEVALLIER, Julien. Econometric Analysis of Carbon Markets: the European Union Emissions Trading Scheme and the Clean Development Mechanism. p.42.

Precipitation and winds: these variables increase the quantity of energy produced by hydraulic and wind power. These allow the production of energy that is low in carbon than fossil fuels and thus reduce the demand for allowances from other energetic industries.

\section{SBF250 and the subprime crisis}

We must take into account the weight of economic activity on electricity production and consequently on the price of the EUA (Bouti and al., 2019).

We claim, then to highlight the effect of the subprime crisis ${ }^{9}$ on companies of the EU Emissions Trading Scheme (EU ETS) for Responsible Management.

With this in mind, we can say that our analysis does suggest the SBF 250 variable, which is listed on NYSE Euronext. ${ }^{10}$

The following Table highlights the members of BlueNext by categories.

Table 3. BlueNext members by categories

\begin{tabular}{|c|c|}
\hline Categories & Share of members (\%) \\
\hline Companies subject to ETS & 41 \\
\hline .. Of which electricity producers & 37 \\
\hline Bank and market participants & 32 \\
\hline Brokers & 20 \\
\hline Credit issuers & 07 \\
\hline
\end{tabular}

Source: El Amri and al. (2020).

It should be noted that economic activity impacts electricity producers (representing $37 \%$ in the carbon market) and companies subject to ETS (41\% share in BlueNext).

\section{Results, discussions and critical issues}

Depending on the share of coal and gas in their electricity mix, power producers may benefit from the opportunity to switch from coal to gas depending on the price of the carbon price of the carbon in order to minimize the electricity production coast.

We consider here the switching between coal and gas to produce one unit of electricity. Oil is mostly used to

${ }^{9}$ Financial crisis that began in October 2008. 
meet high peak demand, especially in winter. Thus, oil is unlikely to interfere with coal and gas switching in the European system. Besides, gas and coal are the cheapest alternatives, while oil has encountered a high level of volatility during the recent period.

The opportunity to switch provides an interesting solution for power to reduce their emissions at low cost. In order to benefit from these cheap abatement opportunities, electricity generators need to compare the $\mathrm{CO} 2$ price and marginal abatement costs.

It may cheaper to switch for a less carbon-intensive fuel (such a gas) instead of using coal and buying permits. That is why, in the power sector, electricity prices are determined by the marginal generation technology. Different generation units are ranked by marginal costs from the cheapest technology to the most expensive one. This ranking is called "merit order", and depends on several parameters such a fuel prices, plant efficiencies and carbon intensity.

The introduction of a carbon cost through tradable permits changes the carbon intensity of power generation technologies and modifies the competitiveness of power plants. Through the introduction of high carbon costs, gas-fired power plants, which are more expensive but less CO2-intensive than coal-fired power plants, may become more profitable than coal-fired power plants. The price of carbon that makes the two technologies equally attractive that is called "switching point".

Without carbon costs, the marginal cost of producing electricity is given by the ratio between fuel costs and the efficiency of the plant.

The switch can only occur if coal-plants are running while some gas plants are available to replace them. The best opportunities occur when the load is relatively low and mostly met by coal-fired plants (during weekends, nights and summers).

Then, with adequate economic incentives, available gas-fired units may be switched. Consequently, the possibility of fuel-switching varies throughout the year depending on the season (winter or summer), the time of the week (day-of-week or week-end effects), and the period of the day (day or night).

As shown in this paper, the influence of such drivers (mainly energy variables and extreme temperatures events) varies depending on the period under consideration and the influence of institutional decisions.

Last but not least, concerning spatial limits, it is worth emphasizing scaling issues. Indeed, increasing the scale of the cap and trade system increases economic efficiency, but also decreases trade security.

In addition, when setting a tradable permits market, the regulator needs to consider deposition constraints, by avoiding excedance of critical loads in specific geographical zones. Another concern lies in the proper design of national emission ceilings.

\section{Conclusion}

In this paper, we have detailed how energy prices related to fuel use (Brent, natural gas, coal) and power producers' fuel -switching behavior (Clean dark spread, clean spark spread, switch price) impact carbon price changes through various regression models. Also, we have detailed the influence of extreme weather events on carbon prices, based on unanticipated temperatures changes.

Carbon Finance will have consequences for the various economic actors, directly for industrial activities and indirectly for the rest of the socio-economic system. According to the literature, market mechanisms have led to the emergence of a carbon price signal, which companies must incorporate into their strategies in order to optimize their reductions in GHG emissions (Nordhaus, 1991). The interest for the company is to understand the ins and outs of Carbon Finance and to make the best use of allocated quotas in order to optimize their economic, financial and environmental performance. Thus, our central question of our research was formulated in the following way:

«What are the responsible issues and sustainable opportunities for the adoption of carbon finance for EU ETS companies for the development of a $2^{\circ} \mathrm{C}$ Finance"? ».

In practice, several determinants of $\mathrm{CO} 2$ prices (EUA) exist to promote the resilience of Carbon Finance, which can be characterized by the price of carbon, primary energy prices: oil, natural gas and coal, Clean Dark Spread, The Clean Spark Spread and the Switch Price, the atmospheric variables and the SBF250 and the 
Subprime crisis. Unlike solutions that are inflexible or irreversible, that increase Climate Change or reduce the incentive to adapt to Carbon Finance would be poorly adopted (Springer, 2003).

The mechanisms of Carbon Finance have a prominent place for the realization of the Sustainable Development (SD) agendas for Carbon Finance to become « Finance $2^{\circ} \mathrm{C}$ ». In these circumstances, not including the anticipation of Climate Change (CC) and the adoption of Carbon Finance (especially the $\mathrm{CO} 2$ exchange system) will increase the risk of making our existence vulnerable to uncertainties while eliminating the actions and carbon transactions available to Sustainable Finance and Sustainable Development (SD). It seems very useful to inject less GHGs in absolute terms, but the real challenge is to reduce the GHGs to a threshold that limits the rise in temperature to $2^{\circ} \mathrm{C}$ (Toth, 1995). To carry out our study, we decided to treat each period of the EU ETS in a different way according to their specificities and the academic work already carried out. In addition to the results of the econometric tool itself and their analysis, the process of sensitizing the industrial players and refocusing reflection on their own interest, that maximizing profitability (or avoid reducing profitability) a project to exchange EU ETS CO2 allowances for current and future climate change.

Author Contributions: conceptualization, El Amri Adil, Boutti Rachid ; methodology, El Amri Adil, Boutti Rachid, Rodhain Florence ; validation, El Amri Adil, Boutti Rachid; formal analysis, El Amri Adil, Boutti Rachid, Oulfarsi Salah, Rodhain Florence; investigation, El Amri Adil, Boutti Rachid, Bouzahir Brahim; resources, El Amri Adil, Boutti Rachid; data curation, El Amri Adil, Rodhain Florence; writing - original draft preparation, El Amri Adil, Boutti Rachid; writing - review and editing, El Amri Adil, Boutti Rachid, Rodhain Florence ; visualization, El Amri Adil, Boutti Rachid ; supervision, Boutti Rachid, Rodhain Florence ; Project administration, Boutti Rachid, Rodhain Florence ; funding acquisition, Boutti Rachid, Rodhain Florence.

\section{References}

1. Alberola, E., Chevallier, J. (2009). European carbon prices and banking restrictions: evidence from Phase I (2005-2007). The Energy Journal, 30(3), 51-79. Retrieved from: https://ideas.repec.org /a/aen/journl/ 2009v30-03-a03.html

2. Alberola, E., Chevallier, J., Cheze B. (2009). Emissions compliances and carbon prices under the EU ETS: a country specific analysis of industrial sectors. Journal of Policy Modelling, 31, 446-462. Retrieved from: https://ideas.repec.org/a/eee/jpolmo/v31y2009i3p446-462.html

3. Alberola, E., Chevallier, J., Cheze B. (2008). Price drivers and structural breaks in European carbon prices 2005-2007. Energy policy, 32(2), 787-797. Retrieved from: https://econpapers.repec.org/ article/eeeenepol/v $3 a 36$ 3ay 3a2008 3ai 3a2 3ap 3a787-797.htm

4. Alcott, B. (2008). The sufficiency strategy: Would rich-world frugality lower environmental impact? Ecological Economics, 770-786. https://doi.org/10.1016/j.ecolecon.2007.04.015

5. Anderson, J. C. et Gerbing, D. W. (1988). Structural equation modelling in practice: A review and recommended two-step approach, Psychological bulletin, 103(3), 411-423. Retrieved from: https://pdfs.semanticscholar.org/2265/a198e55665ed3df0f19688350567dab593de.pdf? ga=2.21391144 7.1042702225.1590342168-1378669878.1588811588

6. Andreas Karaoulanis, A., Vasiliki, K. (2018). Tourism in Developing Countries. The Path Towards Sustainable Development and Its Interaction with The Local Communities, The Environment And The Hu-man Factor. SocioEconomic Challenges, 4(2), 80-86. https://doi.org/10.21272/sec.4(2).80-86.2018

7. Ariely D. (2009). The End of Rational Economics, Harvard Business Review. July-August 2009 Issue. Retrieved from: https://hbr.org/2009/07/the-end-of-rational-economics

8. Aven T. (2015). Implications of black swans to the foundations and practice of risk assessment and management, Reliability Engineering \& System Safety, 134, 83-91. https://doi.org/10.1016/j.ress.2014.10.004

9. Baron, R., Aasrud, A., Sinton, J., Campbell, N., Jiang, K. \& Zhuang, X. (2012). Policy options for low carbon power generation in china. International Energy Agency, Energy Research Institute, Insights Series. 74 p. Retrieved from: http://www.iea.org/publications/insights/insightpublications/Insight PolicyOptions_Low Carbon_China.pdf

10. Bhandari, M.P. (2019). Sustainable Development: Is This Paradigm the Remedy of All Challenges? Does Its Goals Capture the Essence of Real Development and Sustainability? With Reference to Discourses, Creativeness, Boundaries and Institutional Architecture. SocioEconomic Challenges, 3(4), 97-128. https://doi.org/10.21272/sec.3(4).97-128.2019

11. Bhowmik, D. (2019). Decoupling CO2 Emissions in Nordic countries: Panel Data Analysis. SocioEconomic Challenges, 3(2), 15-30. https://doi.org/10.21272/sec.3(2).15-30.2019 
12. Bhowmik, D. (2018). Financial Crises and Nexus Between Economic Growth and Foreign Direct Investment. Financial Markets, Institutions and Risks, 2(1), 58-74. http://doi.org/10.21272/fmir.2(1).5874.2018

13. BONN. (2002). A guide to the climate change convention process. UNFCCC working paper, $49 \mathrm{p}$. Retrieved from: https://unfccc.int/resource/process/guideprocess-p.pdf

14. Boutti, R., El Amri, A., Rodhain, F. (2019). Multivariate Analysis of a Time Series EU ETS: Methods and Applications in Carbon Finance. Financial Markets, Institutions and Risks, 3(1), 18-29. http://doi.org/10.21272/fmir.3(1).18-29.2019.

15. Bożena, S., Vynnychenko, N. (2018). Evaluating of the financial equalization system in Ukraine. Financial Markets, Institutions and Risks, 2(1), 25-36. http://doi.org/10.21272/fmir.2(1).25-36.2018

16. Broome, J. (1992). Counting the costs of global warming. White House Press. Retrieved from: https://philpapers.org/archive/BROCTC-12.pdf

17. Bunn, D., Fezzi, C. (2007). Interaction of European carbon trading and energy prices. Fondazione Eni Enrico Mattei working paper, No. 123, 25 p. Retrieved from : https://www.feem.it/en/publications/feemworking-papers-note-di-lavoro-series/interaction-of-european-carbon-trading-and-energy-prices/

18. Carbon Disclosure Project (CDP). (2010). Supply Chain Report. Retrieved from: www.cdproject.net/CDPResults/CDP-Supply-Chain-Report_2010.pdf

19. CCNUCC. (2007). Investment and Financial Flows to Address Climate Change. Secretariat of the United Nations Framework Convention on Climate Change, Bonn, 272 p. Retrieved from: https://unfecc.int/resource/docs/publications/financial_flows.pdf

20. Chevallier, J. (2012). Econometric Analysis of Carbon Markets: the European Union Emissions Trading Scheme and the Clean Development Mechanism. Springer. Retrieved from: https://www.springer.com/gp/book/ 9789400724112

21. Chin, W. W. (1998). The partial least squares approach to structural equation modeling. Modern methods for business research, 295(2), 295-336. Retrieved from: https://psycnet.apa.org/record/1998-07269-010

22. Christensen, T. H., Godskesen, M. I., Gram-Hanssen, K., Quitzau, M-B., \& Røpke, I. (2007). Greening the Danes? Experience with consumption and environment policies. Journal of Consumer Policy, 30(2), 91-116. https://doi.org/10.1007/s10603-007-9029-2

23. Christiansen, A. C., Arvanitakis, A., Tangen, K. \& Hasselknippe, H. (2005). Price determinants in the EU emissions trading scheme, Climate Policy, 5:1, 15-30. DOI: 10.1080/14693062.2005.9685538

24. Cosgrove-Sacks, C., Dembinski, P. H. (2009). Ehics In Finance: Surviving The Crisis. Finance \& Bien Commun, 1(33), 5-15. Retrieved from: https://www.cairn.info/revue-finance-et-bien-commun-2009-1page-5.htm

25. Dovhan, Z., Kravchuk, I., Karaś, P. (2017). The financial instruments market - an institutional approach. Financial Markets, Institutions and Risks, 1(1), 22-28. http://doi.org/10.21272/fmir.1(1).22-28.2017

26. El Amri, A., Boutti, R., Rodhain, F. (2020). Sustainable Finance at the time of Institutions: Performativity through the lens of Responsible Management in Morocco. Financial Markets, Institutions and Risks, 4(2), 52-64. Retrieved from: https://armgpublishing.sumdu.edu.ua/journals/fmir/volume-4-issue-2/article-6/

27. Ferreira de Araújo Lima, P., Crema, M., Verbano, C. (2020). Risk management in SMEs: A systematic literature review and future directions. European Management Journal, 38:78-94, https://doi.org/10.1016/j.emj.2019.06.005

28. Gadzo S. G., Anaman, Em. At., Pobbi, M., Asiamah, S. K. (2019). Industry Concentration and Asset Quality as Determinate of Financial Performance: A Comparative Study of Indigenous and Foreign Owned Universal Banks. Financial Markets, Institutions and Risks, 3(2), 79-90. http://doi.org/10.21272/fmir.3(2).79-90.2019

29. Hatherick, V. (2020). EU ETS 'passed resilience test' of Covid-19. Argusmedia, Retrieved from: https://www.argusmedia.com/en/news/2109759-eu-ets-passed-resilience-test-of-covid19 
30. Habachi, M., Benbachir, S. (2020). The Bayesian Approach to Capital Allocation at Operational Risk: A Combination of Statistical Data and Expert Opinion. International Journal of Financial Studies, MDPI, Open Access Journal, vol. 8(1), 1-25. Retrieved from: https://www.mdpi.com/2227-7072/8/1/9/pdf

31. Heinemann, S. (2011). Financial Derivatives and Responsibility - How To Deal Ethically With Financial Risk. Finance \& Bien Commun, 1(39), 45-56. Retrieved from: https://www.cairn.info/revue-finance-et-biencommun-2011-1-page- 45.htm

32. IEA Ministerial Statement on Energy and Climate Change. (2015). Energy Matters : How COP 21 can shift the energy sector onto a low-carbon path that supports economic growth and energy access, International Energy Agency, 8 p. Retrieved from: http://www.iea.org/media/presentations/Energy Matters brochure.PDF

33. International Renewable Energy Agency, IRENA. (2014). IRENA communiqué on the Africa clean energy corridor. Africa clean energy corridor ministerial, Abu Dhabi, United Arab Emirats. Retrieved from : http://www.irena.org/DocumentDownloads/events/IRENA_ACEC_Communique 2014.pdf

34. IPCC. (2014). Climate Change 2014: Impacts, Adaptation, and Vulnerability Summary for Policymakers, Cambridge University Press, Cambridge, United Kingdom and New York, NY, USA, 44 p. Retrieved from: https://ipcc-wg2.gov/AR5/images/uploads/IPCC_WG2AR5 SPM_Approved.pdf

35. Jaffe, A.B., R.G. Newell, \& R.N. Stavins (2004). Economics of energy efficiency. 79-90 in Cleveland, C.J. (ed), Encyclopedia of Energy, Volume 2, San Diego and Oxford (UK): Elsevier. Retrieved from: https://scholar.harvard.edu/files/stavins/files/encyclopedia of energy 2004.pdf

36. Kasztelnik, K. (2020). Causal-Comparative Macroeconomic Behavioral Study: International Corporate Financial Transfer Pricing in the United States. Financial Markets, Institutions and Risks, 4(1), 60-75. Retrieved from: http://armgpublishing.sumdu.edu.ua/journals/fmir/volume-4-issue-1/article-5/

37. Kostel, M., Leus, D., Cebotarenco, A., Mokrushina, A. (2017). The Sustainable Development Goals for Eastern Partnership Countries: Impact of Institutions. Socio-Economic Challenges, 1(3), 79-90. http://doi.org/10.21272/sec.1(3).79-90.2017

38. Lebatt, S. et White, R., R., (2007). Carbon finance : the financial implications of climate change. John Wiley \& Sons, Inc. Retrieved from: https://www.wiley.com/enus/Carbon+Finance $\% 3 \mathrm{~A}+$ The+Financial+Implications + of + Climate + Change-p-9780471794677

39. Lieonov, S., Didenko, I. (2017). Assessment of demand, supply and equilibrium price on the deposit market of Ukraine, Financial Markets, Institutions and Risks, 1(1), 5-13. Retrieved from: https://armgpublishing.sumdu.edu.ua/wpcontent/uploads/2016/12/files/fmir/issue1/FMIR 12017 Lieon ov 5-13.pdf

40. Nordhaus, W. D. (1991). To slow or not to slow: the economics of the greenhouse effect. Economic Journal, Vol. 101: 920- 937. Retrieved ffrom:https://www.jstor.org/stable/2233864? seq=1

41. OCDE. (2010). Climate Policy and Technological Innovation and Transfer: an overview of trends and recent empirical analysis: empirical results. Retrieved from: www.oecd.org/dataoecd/54/52/45648463.pdf

42. Popoola, M. Ak., Brimah, Am. N., Gbadeyan, A. R. (2019). Financial Institutions Micro Loans: A Strategy for Reducing Poverty in Nigeria. Financial Markets, Institutions and Risks, 3(3), 1318.http://doi.org/10.21272/fmir.3(3). 13-17.2019.

43. Priem R. L., Rasheed A. M.A., Kotulic A. G. (1995). Rationality in Strategic Decision Processes, Environmental Dynamism and Firm Performance, Journal of Management. Retrieved from: http://journals.sagepub.com/doi/abs/10.1177/014920639502100506

44. Rubanov, P., Marcantonio, A. (2017). Alternative Finance Business-Models: Online Platforms. Financial Markets, Institutions and Risks, 1(3), 92-98. Retrieved from: http://armgpublishing.sumdu.edu.ua/journals/fmir/issue-3/article-9/

45. Rydge, J. (2015). Implementing Effective Carbon Pricing: contributing paper for seizing the global opportnity partnerships for better growth and a better climate, New Climate Economy, London and Washington, DC. Retrieved from : http://www.newclimateeconomy.report/misc/working-papers/

46. Sifah, D. (2009). Ethics: An Essential Prerequisite Of The Financial System. Finance \& Bien Commun, 1(33), 46-57. Retrieved from : https://www.cairn.info/revue-finance-et-bien-commun-2009-1-page- 
46.htm

47. Singh, S.N. (2018). Regional Disparity and Sustainable Development in North-Eastern States of India: A Policy Perspective. Socio-Economic Challenges, 2(2), 41-48. http://doi.org/10.21272/sec.2(2).41- 48.2018

48. Soleimani Zoghi, F. (2017). Risk Management Practices and SMEs: An empirical study on Turkish SMEs. International Journal of Trade, Economics and Finance, 8(2), 123-127. http://10.18178/ijtef.2017.8.2.550

49. Springer, U. (2003). The market for tradable GHG permits under the Kyoto Protocol: a survey of model studies. Energy Economics, 25, 527-551. Retrieved from: https://econpapers.repec.org/ article/eeeeneeco/v_3a25_3ay_3a2003_3ai_3a5_3ap_3a527-551.htm

50. Ted Prince E. (2018). Risk Management and Behavioral Finance. Financial Markets, Institutions and Risks, 2(2), 5-21. Retrieved from: https://armgpublishing.sumdu.edu.ua/journals/fmir/volume-2-issue2/article-1/

51. Toth, F. L. (1995). Discounting in integrated assessments of climate change. Energy Policy, Elsevier, 23(45), 403-409. Retrieved from: https://ideas.repec.org/a/eee/enepol/v23y1995i4-5p403-409.html

52. UNEP FI. (2013). Portfolio carbon: measuring, disclosing and managing the carbon intensity of investments and investment portfolios. UNEP FI Climate Change Advisory and Investment Commission. 40 p. Retrieved from: http://www.unepfi.org/fileadmin/documents/ UNEP FI_Investor_Briefing Portfolio Carbon.pdf

53. Vargas-Hernández, J. G., Orozco-Quijano, E. P., Virchez, J. (2018). Critical Analysis On Institutional Capital On Trade And Environmentally Sustainable Development Under NAFTA. SocioEconomic Challenges, 4(2), 21-31. https://doi.org/10.21272/sec.4(2).21-31.2018

54. Vasilyeva, T., Lyeonov, S., Lopa, L. (2018). Forecasting Supply and Demand In the Regional Labor Market: In Search of Optimal Proportions of Financing Vocational Education Institutions In the Region. SocioEconomic Challenges, 2(1), 69-84. Retrieved from: https://doi.org/10.21272/sec.2(1).69-84.2018

55. Hatherick, V. (2020). EU ETS 'passed resilience test' of Covid-19. Agrusmedia. Retrieved from: https://www.argusmedia.com/en/news/2109759-eu-ets-passed-resilience-test-of-covid19

56. Vidar Gudmundsson S. and Lechner C. (2013). Cognitive Biases, Organization, and Entrepreneurial Firm Survival, European Management Journal, 31(3):278-294, DOI: 10.2139/ssrn.2186062. Retrieved from: https://www.researchgate.net/publication/255725144_Cognitive_Biases_Organization_and_Entrepreneurial_Firm_Survival

57. Wolrd Bank Group (2010). The economics of adaptation to climate change, The World Bank, Washington, D.C., 84 p. Retrieved from: http://siteresources.worldbank.org/EXTCC /Resources/ EACC_FinalSynthesisReport0803 2010.pdf 